\title{
PEMBERDAYAAN IBU-IBU DI BABAKAN MADANNG SENTUL DENGAN PELATIHAN MEMBUAT PRODUK JUMPUTAN
}

\author{
Harsuyanti Lubis ${ }^{1)}$, Revrina Sukma Agusti ${ }^{2)}$, Dewi Suliyanthini ${ }^{3)}$ \\ Fakultas Teknik, Universitas Negeri Jakarta
}

\begin{abstract}
ABSTRAK
Pengabdian Pada Masyarakat (P2M) adalah salah satu dari Tridharma Perguruan Tinggi yang wajib dilaksanakan oleh setiap dosen. Pelaksanaan pengabdian yang berupa pelatihan pembuatan produk jumputan dikarenakan adanya kesenjangan antara penduduk perumahan dan para ibu-ibu yang bertempat tinggal di perkampungan Desa Cipambuan Babakan Madang Sentul yang mana pada umumnya para penduduk hanya bertani singkong dan buruh pengupas singkong.

Pelatihan pembuatan produk jumputan pada kain kerudung dan baju kaos, memberikan motivasi dan kreativitas pada para ibu-ibu di Babakan Madang Sentul, panen singkong dan buruh singkong tidak setiap hari dilakukan, sehingga dalam waktu luangnya mereka dapat mengisi kegiatan kosong dengan membuat produk yang bermanfaat dan memberikan keteranpilan baru bagi para ibu-ibu, yang juga diharaapkan membuka peluang usaha dibidang lain..

Hasil yang diperoleh berupa produk jumputan berupa baju kaos bermotif pelangi dan kain jilbab bermotif pelangi dengan corak warna yang beragam, memberikan semangat dan motivasi para ibu-ibu lebih giat lagi berkreatifitas. .
\end{abstract}

Key word : jumputan, kain pelangi

\section{PENDAHULUAN}

\section{A. Analisis Situasi}

"Sentul City" berimage kan kompleks perumahan elite dengan bentuk rumah yang mewah besar indah dan tentunya harga jual tinggi, dengan penghuni yang sangat glamour. Namun ada hal yang dilupakan, perbatasan dengan kompleks perumahan elite ini terdapat perkampungan desa Babakan Madang Sentul yang penduduknya masih sangat sederhana, umumnya penduduk asli perkampungan sentul ini hanya bertani singkong dan buruh pengupas singkong. Dengan perebedaan kesenjangan sosial ini, timbul Gap atau kesenjangan perbedaan sosial ekonomi

kehidupan antara penduduk asli perkampungan Sentul dengan penduduk kompleks perumahan. Oleh karena itu kami tim Pengabdian pada Masyarakat ingin memberikan sentuhan keterampilan, pengetahuan agar para penduduk mendapatkan pengetahuan dan keterampilan yang dapat dijadikan mereka sebagai penghasilan tambahan guna kelangsungan kehidupan penduduk Babakan Madang Sentul.

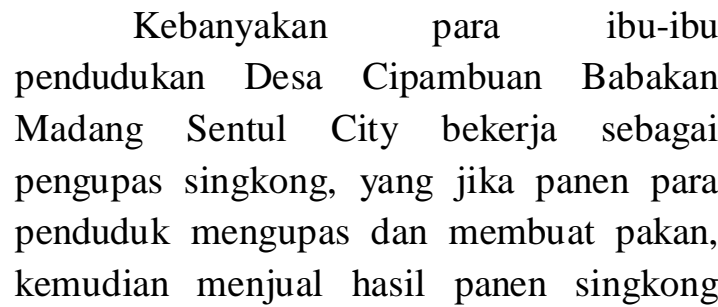


tersebut dengan dijual perkilo $(\mathrm{Kg})$ hanya Rp. 1.000,- (seribu rupiah). Sebagian dari para penduduk hanya menjadi buruh kuli pengupas singkong, dimana upah buruh pengupas hanya Rp 250,- (Dua Ratus lima puluh Rupiah)/Kg. rata-rata para buruh mengupas dari jam 9.00 sampai jam 14.00 sebanyak $10 \mathrm{~kg}$ singkong .

Dari hasil analisa tersebut diatas, kami team pengabdian masyarakat Lembaga Pengabdian Masyarakat Universitas Negeri Jakarta, merasa perlu dan terdorong unttuk memberikan pelatihan kepada para ibu-ibu untuk memberikan kegiatan diwaktu luangnya, sebagai penghasilan tambahan agar mendapatkan income tambahan diluar pekerjaan utamanya sebagai pengupas singkong

Kegiatan membuat produk jumputan selain produk yang dihasilkan dapat digunakan sendiri juga keterampilan membuat jumputan ini dapat mereka lanjutkan untuk membuat produk lain dengan tambahan kreativitas dan kemandirian usaha. Proses pembuatan jumputan pun tidak begitu sulit untuk para ibu-ibu melakukannya, hanya dengan mengikat dengan kuat kain dengan tali rafia dan pewarnaan akan menghasilkan kain yang sebelumnya berwarna putih, setelah proses pencelupan dan membuka talinya, kain akan berwarna pelangi. Oleh karena itu Perumusan Pengabdian ini adalah : "Apakah dengan memberikan program pelatihan pembuatan produk jumputan dapat memberikan manfaat keterampilan, mengisi waktu luang dengan kegiatan positif dan memberikan tamabahan income bagi para ibu-ibu di Babakan Madang Sentul?"

\section{B. Keterkaitan}

Pengabdian Pada Masyarakat (P2M) merupakan salah satu kegiatan Tri Dharma Perguruan Tinggi yang dilaksanakan oleh para dosen Universitas Negeri Jakarta (UNJ). Pelaksanaan P2M ini dilakuukan oleh dosen IKK - FT - INJ bekerjasama dengan Lembaga Pengabdian Masyarakat (LPM) - UNJ. Yang mana dosen Tata Busana memiliki kemampauan memberikan pelatihan, bimbingan, pengetahuan dan keterampilan membuat produk jumputan. Warga desa Cipambuan Babakan Madang Sentul khususnya para ibu-ibu di Sentul sangat membutuhkan program-program pelatihan keterampilan yang bermanfaat dan menciptakan wirausaha, lapangan pekerjaan guna menambah penghasilan warga desa Cipambuan Babakan Madang Sentul. Keterkaitan ini sangatlah bermanfaat bagi warga Babakan Madang dan pengabdian Tri Dharma bagi dosen IKK-FT juga LPM UNJ sebagai wadah yang menaungi, menyebarkan pengetahuan keterampilan, kegiatan Pengabdian pada Masyarakat

\section{TINJUAN PUSTAKA}

Jumputan (tie-dye) adalah kain yang dibuat dengan teknik ikat celup atau seni mengikat dengan memberikan warna pada kain, dalam bahasa Afrika disebut dengan nama adire, sedangkan dalam bahasa India disebut dengan nama badhana dan dalam bahasa Jepang disebut shibori.

Kata-kata itu telah digunakan selama berabad-abad untuk menggambarkan cara membuat desain pada kain yang disebut jumputan atau seni ubar ikat.

Dalam proses ini kain dijumput pada beberapa bagian tertentu, diikat dengan tali karet, lalu dicelup dalam larutan zat warna kain. Kain akan menyerap zat warna kecuali bagian-bagian yang diikat. Dengan demikian terbentuklah pola-pola seperti yang diinginkan.

Jumputan merupakan salah satu cara untuk mencegah terserapnya zat warna oleh 
bagian-bagian yang diikat. Cara-cara lain untuk menghindari terserapnya zat warna adalah dengan menggunakan lilin, balok kayu, setiksetik jahitan, yang pada prinsipnya adalah bagian kain yang tertutupi tidak akan terkena zat warna.

Setelah dicelup, tali-tali dibuka kemudian pada bagian tengah-tengah dari warnawarna putih bekas ikatan tali diberi warna dengan dicoletkan, maka terjadilah kain yang indah. Suatu ciri dari pada kain ini adalah bahwa batas antara warna dasar dan putih tidak merupakan suatu garis melainkan suatu garis yang menggelombang yang memiliki nilai seni yang tinggi dan indah sekali.

Motif dengan teknik seni jumput ini berasal dari Timur Jauh, mungkin sejak 3000 tahun sebelum masehi. Orang Roma salah satu bangsa pertama yang mengimpor kain dari Timur, terpesona oleh cara mewarnai kain katun India dan kain sutera halus Cina. Meskipun teknik ikat tersebut tampaknya rumit, namun lambat laun teknik ikat ini digunakan juga du dua negara yang sangat berjauhan, yakni Cina dan Peru .

Banyak ahli berpendapat bahwa seni ikat jumput ditemukan secara terpisah diberbagai belahan dunia. Di India, Cina, Jepang, Amerika Selatan dan Afrika, banyak orang desa yang masih mempunyai tempat khusus untuk teknik jumputan kain. Ditempat-tempat inilah para pembuat kain jumput berkumpul, dikelilingi bak-bak pencelupan

Bak pencelupan ini bervariasi besarnya bergantung pada besar kecilnya kain jumput, dan berisi zat warna yang warna-warni cemerlang. Beberapa kain ikatan yang telah diikat dan dicelup dalam larutan zat warna kain, kemudian dibilas di dalam air sungai dan dibentangkan agar kering. Ada kain yang diikatkan dan dicelup sampai delapan kali, tergantung pada rumitnya pola motif yang dikehendaki.

Setelah dicelupkan kedalam larutan pewarna, dan dibuka ikatannya, maka akan didapatkan motif mawar berbelit

\section{MATERI DAN METODA}

Metoda kegiatan ini adalah berupa eksperimen, praktek langsung dengan pengarahan dan demonstrasi langsung yang dilakukan 4 kali pertemuan.

Kegiatan ini meliputi :

a. $30 \%$ pengetahuan berupa ceramah dan pemberian informasi tentang proses pembuatan sablon

b. $70 \%$ berupa praktek langsung mempersilahkan para satpam mengerjakan keteranpilan ini dengan inovasinya sendiri.

\section{A. Materi Kegiatan}

\section{Alat dan Bahan}

- Jarum jahit dan benang nylon.

- Tali rafia

- Karet gelang

- Manik-manik, kelereng, uang logam, dll

- Sumpit, Paralon, dll.

- Gunting.

- Carter/pisau potong.

- Zat warna (wantek) bermacammacam warna.

- Kain katun warna putih (kain jilbab) 20 lembar

- Baju kaos katun warna putih 20 baju

Alat bantu dalam pembuatan kain jumputan:

- Sarung tangan plastik atau karet

- Kompor dan panci

- Pengaduk kayu

- Ember dan baskom. 


\section{B. Teknik Pembuatan Motif Jumptan}

Jumputan merupakan salah satu teknik menghasilkan motif pada kain yang dicelup dengan mencegah terserapnya zat warna oleh bagian-bagian yang diikat. Bagian-bagian yang terkat tersebut akan menghasilkan suatu motif, teknik ikatan yang berbeda, akan menghasilkan motif yang berbeda pula. Berikut ini beberapa motif jumputan :

\section{Motif ikatan mawar:}

a. Cubitlah bagian kain.

b. Ikat kuat dengan tali rafia atau karet

c. Setelah dicelupkan kedalam larutan pewarna, dan dibuka ikatannya, maka akan didapatkan motif mawar

\section{Motif ikatan mawar berbelit}

a. Cubitlah bagian kain putih.

b. Ikat kuat dengan membelitkan tali sampai puncak kemudian lilitkan kembali sampai awal ikatan, ikat kuat

c. Setelah dicelupkan kedalam larutan pewarna, dan dibuka ikatannya, maka akan didapatkan motif mawar berbelit

\section{HASIL DAN PEMBAHASAN}

Kegiatan P2M yang dilakukan oleh para ibu-ibu di Sentul. Melalui kegiatan pembuatan produk jumputan di atas baju kaos dan kain katun jilbab yang bertempat di Madrasah/paud yang sudah lama tidak dimanfaatkan.

Peserta kegiatan ini jumlah seluruhnya ada 15 orang, yang rata-rata sebagai ibu rumah tangga. Faktor kendala pada saat pelatihan ini adalah : faktor internal para ibu-ibu yang agak sulit mendapatkan ijin dari para suaminya untuk keluar rumah. Sehingga pada saat pelatihan banyak para ibu yang sambil membawa anak balita, terlambat datang karena harus mengerjakan terlebih dahulu pekerjaan rumah, dan factor jarak antara rumah dengan lokasi pelatihan agak jauh. Dimana lokasi pelatihan dilakukan di pondok PAUD/Madrasah yang sudah tidak aktif lagi. Dan rumah tempat tinggal para ibu ada yang berjarak lebih dari $2 \mathrm{~km}$ tanpa kendaraan. Sehingga saat pelatihan hari selanjutnya ada para ibu yang tidak bisa mengikuti kembali kegiatan ini.

Motivasi dan semangat para peserta dan para juara lomba kami beri hadiah sebagai dorongan semangat atas keberhasilan mereka membuat produk dan meminta para peseserta untuk terus berkaraya dan terus membuat produk. Dimana hasil karya peserta dipakai sendiri oleh para ibu-ibu. Menurut komentar para ibu mereka amat senang dan menyukai program pelatihan ini, karena mendapatkan wawasan pengetahuan dan keterampilan. Kreativitas para ibu-ibu dengan semangat mencoba berbagai bentuk ikatan dan bermacam warna. Sehingga terbersit dalam semangat ibu-ibu untuk mencoba melakukan pembuatan produk jumputan ini sendiri pada kain putih yang telah usang yang mereka miliki sendiri dirumah.

Kegiatan diatas jelas memberikan dampak positif bagi peserta dan memberikan lahan pekerjaan wirausaha sebagai income tambahan mereka. Hampir seluruh peserta menyambut gembira kegiatan ini, sehingga peserta semakin semangat dan termotivasi. Untuk sementara ini hasil kegiatan ini belum memberikan penghasilan tambahan bagi para ibu-ibu, paling tidak hasil kegiatan ini hanya baru memberikan pengetahuan dan keterampilan yang bermanfaat. Namun kami tim P2M telah memberikan modal pada ibuibu di Desa Cipambuan Babakan Madang 
Sentul ini berupa kompor gas, tabung gas $3 \mathrm{~kg}$, panic besar 2 buah lengkap dengan pengaduknya. Bermacam macam warna zat warna wantek, tali raffia. Sehingga para ibuibu dapat melanjutkan sendiri membuat produk jumputan ini.

\section{KESIMPULAN}

Kegiatan pelatihan jumputan kepada para ibu-ibu di Babakan Madang Sentul tercapai secara berkala, bertahap dan berkelanjutan, sesuai dengan tujuan program kegiatan memberikan keterampilan, pengetahuan mengenai proses pembuatan produk kain jumputan untuk mengisi waktu luang, memberikan semangat, motivasi kreativitas untuk berkarya sehingga berusaha dapat menciptakan lapangan pekerjaan yang menghasilkan tambahan penghasilan bagi para ibu-ibu di Babakan Madang Sentul.

Pencapaian target secara berkala ini sewajarnya tercapai karena kondisi social ekonomi pengetahuan pendidikan para ibuibu yang masih minim terbelengu dengan karakter wanita dimasa lalu yang serba terbatas dengan ilmu pengetahuan.

\section{DAFTAR PUSTAKA}

[1] Agus Soeprapto. Pencelupan. Institut Teknologi Tekstil. Bandung. 2009

[2] Dewi Suliyanthini. RPKPS. Rencana Program Perkualiahan Semester. Mata Kuliah Pengetahuan Tekstil. 2013. IKK-FT-UNJ.

[3] Dewi Suliyanthini. Seni Menghias Kain. Seri 1. Jumputan. Gramedia. Jakarta. 2012. 